\title{
Review
}

\section{Dietary N-3 Fatty Acid Supplementation in Rheumatoid Arthritis-Mechanisms, Clinical Outcomes, Controversies, and Future Directions}

\author{
Dianne VOLKER and Manohar GARG* \\ Discipline of Nutrition and Dietetics, Faculty of Medicine \\ and Health Sciences, University of Newcastle, \\ Callaghan, NSW 2308, Australia
}

(Received December 4, 1995)

Summary Studies on the use of dietary n-3 fatty acids supplementation in patients with rheumatoid arthritis started to appear in the scientific literature in the early 1980's. Interest in n-3 fatty acid-modified diets developed further when it was observed that such diets in animal models partly alleviated autoimmune-induced inflammatory disease. Human studies indicate that n-3 fatty acids may reduce inflammation; however, the mechanism of these effects have not been fully elucidated. Inflammatory stimuli result in cytokine production and free radical release, which may enhance the production of tissue necrosis factor (TNF) and cytokines other than those produced through the cyclooxygenase and 5-lipoxygenase enzyme systems and the platelet-activating factor (PAF) system. Clinical manifestations of rheumatoid arthritis have been established by the American College of Rheumatology. The diagnostic criteria most commonly used in the clinical management of rheumatoid arthritis include prolonged morning stiffness, swelling and pain in more than one joint, commonly involving the hands, wrists, knees, and feet in a symmetrical pattern, and an ESR (erythrocyte sedimentation rate) of at least $28 \mathrm{~mm} / \mathrm{h}$. Systemic symptoms associated with active disease include low-grade fever, weakness, and extra articular manifestations such as vasculitis, neuropathy, and pleuritis. There are inconsistencies reported in the literature regarding the effects of n-3 fatty acid supplementation on these clinical parameters. Controversies associated with n-3 fatty acids and rheumatoid arthritis studies may be associated with the crossover design protocol which is not appropriate because of the long carry over effects of fish oils. Also, a study length of less than 12 weeks is insufficient for alteration of cellular lipid levels. Another source

* To whom correspondence should be addressed. 
of confusion is that the level of supplementation with n-3 fatty acids has not been dose related, and there has not been any control of linoleic acid levels in the background diet. The purpose of this article is to review the recent studies utilizing n-3 fatty acids in clinical investigations of patients with rheumatoid arthritis and to suggest directions for future research efforts.

Key Words: n-3 fatty acids, rheumatoid arthritis, mechanisms, controversies, clinical outcomes

Rheumatoid arthritis (RA) is a chronic systemic disorder of unknown etiology that is dominated by the serious and debilitating events associated with progressive destruction of articular joints. The prevalence of RA ranges between $0.3-1.5 \%$ with a female to male ratio of $3: 2$, and the most common age range of onset varies between 16 and 50 years. Evidence for a genetic predisposition is derived from studies of the Major Histocompatibility Complex (MHC) class II molecules indicating that the relative risk of developing RA is several times greater in individuals who inherit HLA-DR1 or DR3, specifically Dw4 and Dw14 [1].

Usually, RA begins insidiously, and diagnosis is dependent on a pattern of clinical manifestations. Diagnostic criteria have been established by the American College of Rheumatology and include prolonged morning stiffness; swelling of more than one joint, commonly involving the hands, wrists, knees and feet in a symmetrical pattern; radiographic evidence of erosive changes in articular bones; subcutaneous nodules over bony prominences, and the presence of serum rheumatoid factor. Systemic symptoms may include low-grade fever, weakness, and extra articular manifestations such as vasculitis, neuropathy, and pleuritis [2-4].

Clinical management of RA is predominantly directed towards pain relief, suppression of inflammation, preservation of joint function, and minimization of systemic complications. These objectives generally necessitate the use of potentially toxic drug therapy including anti-inflammatory, immunosuppressive, or cytotoxic agents, as well as physical and occupational therapy. The drugs used to control rheumatoid arthritis can be grouped into four main categories: Simple analgesics such as paracetamol are used to relieve pain only and are short acting. The non-steroidal anti-inflammatory drugs (NSAIDS) such as aspirin, naproxin, and indomethacin block the metabolism of arachidonic acid to prostaglandins by inhibiting the cyclo-oxygenase enzyme system. This class of drugs is not suitable for use where peptic ulcer disease, ulcerative colitis, or allergy exist, in view of the high doses required to achieve an anti-inflammatory effect. These drugs are short acting with a rapid onset of effectiveness. Disease-modifying anti-rheumatic drugs (DMARDS) such as sulphasalizine, hydroxychloroquine, gold, methotrexate, and penicillamine are active in the inhibition of the cellular immune response. In most cases it is not known how the disease is suppressed by these drugs; however, rashes 
and allergies are common, and onset of their effectiveness is slow. Steroidal drugs such as cortisone, hydrocortisone, prednisolone, and prednisone decrease inflammatory reactions and are short acting with an early effect, but may also produce adverse systemic reactions. Cytotoxic drugs such as methotrexate are immunosuppressants that can induce complete remission, are steroid sparing, but may produce a slightly increased risk of lymphoproliferative disease. Despite these therapeutic interventions, the disease frequently progresses over several years, leading to increasing limitations of joint function with attendant diminished functional status $[3,5-10]$.

There is no known cure for RA, and drug treatment is not very successful. However, RA patients are prone to adopt unproven dietary remedies, such as herbal remedies, green-lipped mussel extract, vegan diet, macrobiotics, and psionic medicine to reduce inflammatory activity [11]. Many experimental studies have provided evidence that incorporation of $n-3$ fatty acids into tissues may modify inflammatory and immune reactions, as n-3 fatty acids are potent therapeutic agents for inflammatory diseases $[7,9,11-18]$. This article will include a review of recent studies in the literature, a critique of recent studies, and possible directions for future studies based on the mechanisms proposed.

\section{MECHANISMS}

Interest in the use of n-3 fatty acid dietary supplements in patients with autoimmune-induced inflammatory disease arose from earlier investigations in animal models and epidemiological studies [19, 20]. Eicosanoid metabolism in humans involves arachidonic acid (AA) as the precursor of the 2-series prostanoids (prostaglandins and thromboxanes) and of leukotrienes of the 4 series. When humans ingest fish oil containing the n-3 fatty acids, eicosapentaenoic acid (EPA) and/or docosahexaenoic acid (DHA) partially replace the n-6 fatty acids, particularly arachidonic acid, in membrane phospholipids. This occurs in all the tissues at the cellular level, particularly in the membrane phospholipids of platelets, erythrocytes, neutrophils, monocytes, and brain and liver cells. As a result, ingestion of EPA and DHA from fish oils leads to the production of thromboxane A-3 and prostacyclin I-3 with a net physiologic shift that favors decreased platelet aggregation via suppression of the cyclo-oxygenase pathway and suppression of inflammatory mediator synthesis; that occurs via the 5-lipoxygenase synthesis pathway. The latter is involved because prostacyclin I-3 retains its vasodilatory and antiaggregatory properties, whereas thromboxane A-3 does not retain its proaggregatory, vasoconstrictive activity. Fish oil supplementation also results in the decreased production of leukotriene B4 (LTB4), derived from arachidonate through the competitive inhibition of the 5-lipoxygenase pathway, with the new production of LTB5 from EPA. LTB5 is a weak inducer of inflammation and chemotaxis; and since LTB4 is a potent inflammatory and chemotactic compound, an overall decrease in its production can be expected to

Vol. 20, No. 2, 1996 
favorably affect the clinical manifestations of RA [15, 16, 21-28]. However, no study has reported that LTB4 levels and/or production is increased in RA active disease compared with its level in normal individuals.

There is evidence in the literature that AA for eicosanoid production may arise via a phospholipase A2 action specific for alkyl-acyl-PC rather than the diacyl-PC with resulting formation of PAF. This would be very economical for the cell as two biologically active compounds would be generated in one pathway. PAF, which is the most potent inflammatory substance known to date, has been shown to be suppressed by dietary $\mathrm{n}-3$ supplementation in human and animal studies [29]. PAF production in RA patients supplemented with fish oils containing n-3 fatty acids has been shown to be suppressed; thus this may represent a potential mechanism by which n-3 fatty acids may exhibit beneficial effects in these patients.

Das [30] reports that $n-3$ fatty acids such as EPA and DHA can suppress T cell proliferation and the production of interleukin-1 (IL-1), interleukin-2 (IL-2), and tumour necrosis factor (TNF). Endres et al. [31] suggested that as IL-1 and TNF are principal mediators of inflammation, reduced production of these cytokines may contribute to the amelioration of inflammatory symptoms in patients with rheumatoid arthritis taking n-3 fatty acid supplementation. Modulation of the severity of RA through the use of fish oil (n-3 fatty acid) supplementation could have a significant impact on our understanding of the etiology of the condition. The need to use potentially toxic drugs to combat inflammation and achieve immunosuppression could be reduced through the combination of NSAIDS and n-3 fatty acids and/or DMARDS and n-3 fatty acids. This would represent a significant advancement in the treatment process, which is merely palliative at present $[11,17]$.

The two most commonly used acute-phase reactants in the evaluation of rheumatic diseases are the erythrocyte sedimentation rate (ESR) and the C-reactive protein (CRP). The CRP level responds more rapidly than the ESR to changes in inflammatory activity and thus would be a more sensitive measure of inflammation. However, the ESR takes only $1 \mathrm{~h}$ and simple equipment, whereas the CRP is assayed by radioimmunodiffusion and requires $24 \mathrm{~h}$. The ESR can be a good predictor of disease activity in RA but is susceptible to other influences such as age, gender, pregnancy, anemia, and anti-inflammatory drugs [32].

The role of diet in the treatment of RA would be concerned with correcting the dietary imbalance of n-6 and n-3 fatty acids. The human body cannot synthesize linolenic acid; however, if linolenic acid is present in the diet, the body can synthesize EPA and DHA. To effectively increase body stores of EPA and DHA, the RA patient must consume them either in the form of vegetable oils rich in linolenic acid (flaxseed, canola or soybean oils) or as marine oils. The typical western diet has sufficient amounts of n-6 fatty acids but lacks optimal amounts of n-3 fatty acids. The dietary imbalance is primarily due to a high intake of vegetable 
oils (such as safflower seed, corn, and cottonseed oil) and a limited intake of fats providing $\mathrm{n}-3$ fatty acids.

\section{ANALYSIS OF PUBLISHED DATA}

A study conducted at the University of Florida and published in 1983 examined the effects of a rice, fish, and vegetable diet on patients with active RA and observed no difference between experimental and control diets. However, a small number of patients on the control diet did improve significantly from baseline, but the overall improvement in the study cohort was not statistically significant. This study did not involve n-3 fatty acid supplementation but may have had n-3 fatty acids as a result of the fish-based diet. The experimental diet was a specific diet free of additives, preservatives, fruit, red meat, herbs, and dairy products [33].

In a pilot study from the Albany Medical College, U.S.A., published in 1985, 17 patients with active RA consumed an experimental diet high in polyunsaturated fatty acids (PUFA) and low in saturated fatty acids (SFA) with a daily fish oil supplement of $1.8 \mathrm{~g}$ EPA and $0.9 \mathrm{~g}$ DHA [34]. A control group consumed a diet with a PUFA/SFA ratio of $1: 4$ and took a capsule of indigestible paraffin wax. All patients were taking NSAIDS. Compliance was measured by patient diaries, pill counts, and gas chromatographic analysis of plasma lipids in order to document the rise in plasma EPA in patients consuming fish oils. The study was double-blind, placebo-controlled, randomized, and of 12 weeks' duration, with a follow-up evaluation at 1 and 2 months after the discontinuation of the trial. Clinical measures of RA activity were made at the fourth, eighth, and twelfth week and at follow-up evaluations. The results showed a significant difference in morning stiffness between the two groups at the time of the twelfth week evaluation. This was apparent in the worsening of the control group, whereas the lowfat group remained unchanged. Other parametric changes (see Table 1), such as the improvement in the mean number of swollen joints compared with baseline measures, were not statistically significant.

In a subsequent clinical investigation at Albany Medical College in 1987, the effects of fish oil dietary supplementation alone was investigated in a 14-week, double-blind, placebo-controlled crossover investigation with a 4-week washout period between study arms [35]. Patients with active RA received $2.7 \mathrm{~g}$ EPA and $1.8 \mathrm{~g}$ DHA daily or $4.5 \mathrm{~g}$ of olive oil (8\% $\mathrm{n}-6)$. The crossover design allowed investigators to compare the effects of fish oil versus olive oil supplementation in the same individuals while they maintained their own background diets, supplements (if any), and medications without alterations. Thirty-three patients completed the study with satisfactory compliance documented by pill counts and gas chromatographic analysis of plasma fatty acids. Treatment with NSAIDS, DMARDS, and prednisone was continued. The fish oil supplementation was well tolerated and resulted in some statistically significant clinical improvements in 
Table 1. Comparison of effects of $n-3$ supplementation on clinical parameters.

\begin{tabular}{|c|c|c|c|c|c|}
\hline References & Study design & Duration & Amount $n-3$ & $\begin{array}{c}\text { Clinical } \\
\text { parameters }\end{array}$ & Effect \\
\hline \multirow[t]{5}{*}{$\begin{array}{l}\text { Kremer, } \\
1985[34]\end{array}$} & $\begin{array}{l}\text { Placebo- } \\
\text { controlled }\end{array}$ & 12 weeks & $1.8 \mathrm{~g} \mathrm{EPA}$ & Morning stiffness & + \\
\hline & Double-blind & & & Onset fatigue & + \\
\hline & Randomized & & & Grip strength & + \\
\hline & Prospective & & & Walk time & NE \\
\hline & & & & Tender joints & ++ \\
\hline \multirow[t]{5}{*}{$\begin{array}{l}\text { Kremer, } \\
1987[35]\end{array}$} & $\begin{array}{l}\text { Placebo- } \\
\text { controlled }\end{array}$ & $\begin{array}{l}2 \times 14 \\
\text { weeks }\end{array}$ & $2.7 \mathrm{~g} \mathrm{EPA}$ & Morning stiffness & NE \\
\hline & Doube-blind & & $1.8 \mathrm{~g} \mathrm{DHA}$ & Onset fatigue & ++ \\
\hline & Randomized & & & Grip strength & NE \\
\hline & Crossover & & & Walk time & NE \\
\hline & Prospective & & & Tender joints & ++ \\
\hline \multirow{2}{*}{$\begin{array}{l}\text { Sperling, } \\
1987[36]\end{array}$} & Blind & 6 weeks & $3.6 \mathrm{~g}$ EPA & Joint pain index & + \\
\hline & Prospective & & $2.0 \mathrm{~g} \mathrm{DHA}$ & Pt assessment & + \\
\hline \multirow[t]{4}{*}{$\begin{array}{l}\text { Cleland, } \\
1988 \text { [37] }\end{array}$} & $\begin{array}{l}\text { Placebo- } \\
\text { controlled }\end{array}$ & 12 weeks & $3.2 \mathrm{~g} \mathrm{EPA}$ & Morning stiffness & + \\
\hline & Double-blind & & $2.0 \mathrm{~g} \mathrm{DHA}$ & Grip strength & ++ \\
\hline & Randomized & & & Walk time & NE \\
\hline & Prospective & & & Tender joints & ++ \\
\hline \multirow[t]{4}{*}{$\begin{array}{l}\text { Kremer, } \\
1990 \text { [39] }\end{array}$} & $\begin{array}{l}\text { Placebo- } \\
\text { controlled }\end{array}$ & 24 weeks & $27 \mathrm{mg} / \mathrm{kg} /$ day EPA & Morning stiffness & ++ \\
\hline & Double-blind & & $18 \mathrm{mg} / \mathrm{kg} /$ day DHA & Onset fatigue & + \\
\hline & Randomized & & $54 \mathrm{mg} / \mathrm{kg} /$ day EPA & Grip strength & ++ \\
\hline & Prospective & & $36 \mathrm{mg} / \mathrm{kg} /$ day DHA & $\begin{array}{l}\text { Tender joints } \\
\text { Swollen joins }\end{array}$ & $\begin{array}{c}++ \\
+\end{array}$ \\
\hline \multirow[t]{4}{*}{$\begin{array}{l}\text { Van Tempel, } \\
1990[40]\end{array}$} & $\begin{array}{l}\text { Placebo- } \\
\text { controlled }\end{array}$ & 12 weeks & $2.04 \mathrm{~g} \mathrm{EPA}$ & Morning stiffness & ++ \\
\hline & Double-blind & & $1.32 \mathrm{~g} \mathrm{DHA}$ & Tender joints & $\mathrm{NE}$ \\
\hline & Randomized & & & Swollen joints & + \\
\hline & Crossover & & & Grip strength & $\mathrm{NE}$ \\
\hline \multirow[t]{4}{*}{$\begin{array}{l}\text { Skoldstam, } \\
1992 \text { [41] }\end{array}$} & $\begin{array}{l}\text { Placebo- } \\
\text { controlled }\end{array}$ & 24 weeks & $1.8 \mathrm{~g} \mathrm{EPA}$ & Grip strength & $\mathrm{NE}$ \\
\hline & Double-blind & & $1.2 \mathrm{~g} \mathrm{DHA}$ & Ritchie index & NE \\
\hline & Randomized & & & Dr/global/eval & NE \\
\hline & Non-crossover & & & NSAIDS reduction & + \\
\hline \multirow[t]{4}{*}{$\begin{array}{l}\text { Nielsen, } \\
1992 \text { [42] }\end{array}$} & $\begin{array}{l}\text { Placebo- } \\
\text { controlled }\end{array}$ & 12 weeks & $2.0 \mathrm{~g} \mathrm{EPA}$ & Morning stiffness & ++ \\
\hline & Double-blind & & $1.2 \mathrm{~g} \mathrm{DHA}$ & Grip strength & + \\
\hline & Randomized & & & Tender joints & + \\
\hline & & & & NSAIDS reduction & $\mathrm{NE}$ \\
\hline \multirow[t]{3}{*}{$\begin{array}{l}\text { Lau, } \\
1993 \text { [43] }\end{array}$} & $\begin{array}{l}\text { Placebo- } \\
\text { controlled }\end{array}$ & 52 weeks & $1.71 \mathrm{~g} \mathrm{EPA}$ & Morning stiffness & NE \\
\hline & Double-blind & & $1.14 \mathrm{~g} \mathrm{DHA}$ & Grip strength & $\mathrm{NE}$ \\
\hline & Randomized & & & Pain & NE \\
\hline \multirow{6}{*}{$\begin{array}{l}\text { Guesens, } \\
1994 \text { [6] }\end{array}$} & & 52 weeks & $2.6 \mathrm{~g} \mathrm{EPA} / \mathrm{DHA}$ & $\begin{array}{l}\text { NSAIDS reduction } \\
\text { Morning stiffness }\end{array}$ & $\stackrel{+}{N E}$ \\
\hline & controlled & & & & \\
\hline & Double-blind & & & Grip strength & + \\
\hline & Randomized & & & Ritchie index & NE \\
\hline & & & & $\mathrm{Dr} /$ global disease & + \\
\hline & & & & Patient pain assess & + \\
\hline
\end{tabular}

++ , highly significant improvement; + , significant improvement; NE, no effect. 
DIETARY N-3 FATTY ACIDS AND RHEUMATOID ARTHRITIS

Table 2. Comparison of effects of n-3 supplementation on biochemical parameters.

\begin{tabular}{|c|c|c|c|c|c|}
\hline References & Study design & Duration & Amount $n-3$ & $\begin{array}{c}\text { Biochemical } \\
\text { parameters }\end{array}$ & Effect \\
\hline $\begin{array}{l}\text { Kremer, } \\
1985[34]\end{array}$ & $\begin{array}{l}\text { Placebo- } \\
\quad \text { controlled } \\
\text { Double-blind } \\
\text { Randomized } \\
\text { Prospective }\end{array}$ & 12 weeks & $1.8 \mathrm{~g} \mathrm{EPA}$ & None observed & \\
\hline $\begin{array}{l}\text { Kremer, } \\
1987 \text { [35] }\end{array}$ & $\begin{array}{l}\text { Placebo- } \\
\quad \text { controlled } \\
\text { Double-blind } \\
\text { Randomized } \\
\text { Crossover } \\
\text { Prospective }\end{array}$ & $\begin{array}{l}2 \times 14 \\
\text { weeks }\end{array}$ & $\begin{array}{l}2.7 \mathrm{~g} \text { EPA } \\
1.8 \mathrm{~g} \mathrm{DHA}\end{array}$ & $\begin{array}{l}\text { Leukotriene (B4) } \\
\text { Leukotriene (B5) }\end{array}$ & $\begin{array}{c}++ \\
+\end{array}$ \\
\hline $\begin{array}{l}\text { Sperling, } \\
1987 \text { [36] }\end{array}$ & $\begin{array}{l}\text { Prospective } \\
\text { Blind }\end{array}$ & 6 weeks & $\begin{array}{l}3.6 \mathrm{~g} \text { EPA } \\
2.4 \mathrm{~g} \mathrm{DHA}\end{array}$ & $\begin{array}{l}\text { Leukotriene (B4) } \\
\text { PAF }\end{array}$ & $\begin{array}{l}+ \\
+\end{array}$ \\
\hline $\begin{array}{l}\text { Cleland, } \\
1988 \text { [37] }\end{array}$ & $\begin{array}{l}\text { Placebo- } \\
\quad \text { controlled } \\
\text { Double-blind } \\
\text { Randomized } \\
\text { Prospective }\end{array}$ & 12 weeks & $\begin{array}{l}3.2 \mathrm{~g} \mathrm{EPA} \\
2.0 \mathrm{~g} \mathrm{DHA}\end{array}$ & $\begin{array}{l}\text { Leukotriene (B4) } \\
\text { Leukotriene (B5) } \\
\text { combined }\end{array}$ & $\begin{array}{l}+ \\
+\end{array}$ \\
\hline $\begin{array}{l}\text { Kremer, } \\
1990[39]\end{array}$ & $\begin{array}{l}\text { Placebo- } \\
\quad \text { controlled } \\
\text { Double-blind } \\
\text { Randomized } \\
\text { Prospective }\end{array}$ & 24 weeks & $\begin{array}{l}27 \mathrm{mg} / \mathrm{kg} / \text { day EPA } \\
18 \mathrm{mg} / \mathrm{kg} / \text { day DHA } \\
54 \mathrm{mg} / \mathrm{kg} / \text { day EPA } \\
36 \mathrm{mg} / \mathrm{kg} / \text { day DHA }\end{array}$ & $\begin{array}{l}\text { Leukotriene (B4) } \\
\text { Interleukin (1) } \\
\text { Interleukin (2) }\end{array}$ & $\begin{array}{l}++ \\
\mathrm{NE} \\
\mathrm{NE}\end{array}$ \\
\hline $\begin{array}{l}\text { Van Tempel, } \\
1990[40]\end{array}$ & $\begin{array}{l}\text { Placebo- } \\
\quad \text { controlled } \\
\text { Double-blind } \\
\text { Randomized } \\
\text { Crossover } \\
\text { Prospective }\end{array}$ & 12 weeks & $\begin{array}{l}2.04 \mathrm{~g} \mathrm{EPA} \\
1.32 \mathrm{~g} \mathrm{DHA}\end{array}$ & $\begin{array}{l}\text { Leukotriene (B4) } \\
\text { Leukotriene (B5) }\end{array}$ & $\begin{array}{l}\mathrm{NE} \\
\mathrm{NE}\end{array}$ \\
\hline $\begin{array}{l}\text { Skoldstam, } \\
1992 \text { [41] }\end{array}$ & $\begin{array}{l}\text { Placebo- } \\
\text { controlled } \\
\text { Double-blind } \\
\text { Randomized }\end{array}$ & 24 weeks & $\begin{array}{l}1.8 \mathrm{~g} \mathrm{EPA} \\
1.2 \mathrm{~g} \mathrm{DHA}\end{array}$ & $\begin{array}{l}\text { ESR } \\
\text { CRP } \\
\text { Platelet count }\end{array}$ & $\begin{array}{l}+ \\
\mathrm{NE} \\
\mathrm{NE}\end{array}$ \\
\hline $\begin{array}{l}\text { Nielsen, } \\
1992[42]\end{array}$ & $\begin{array}{l}\text { Placebo- } \\
\text { controlled } \\
\text { Double-blind } \\
\text { Randomized }\end{array}$ & 12 weeks & $\begin{array}{l}2.0 \mathrm{~g} \mathrm{EPA} \\
1.2 \mathrm{~g} \mathrm{DHA}\end{array}$ & $\begin{array}{l}\text { ESR } \\
\text { CRP }\end{array}$ & $\begin{array}{l}\mathrm{NE} \\
+\end{array}$ \\
\hline $\begin{array}{l}\text { Lau, } \\
1993 \text { [43] }\end{array}$ & $\begin{array}{l}\text { Placebo- } \\
\text { controlled } \\
\text { Double-blind }\end{array}$ & 52 weeks & $\begin{array}{l}1.71 \mathrm{~g} \mathrm{EPA} \\
1.14 \mathrm{~g} \mathrm{DHA}\end{array}$ & None observed & \\
\hline $\begin{array}{l}\text { Guesens, } \\
1994 \text { [6] }\end{array}$ & $\begin{array}{l}\text { Placebo- } \\
\text { controlled } \\
\text { Double-blind } \\
\text { Randomized }\end{array}$ & 52 weeks & $2.6 \mathrm{~g} \mathrm{EPA} / \mathrm{DHA}$ & ESR & NE \\
\hline
\end{tabular}

++ , highly significant improvement; + , significant improvement; NE, no effect. 
disease activity (see Table 1). LTB4 production decreased by $57.8 \%$ (see Table 2) and remained below baseline measures for 18 weeks after the fish oil supplementation had ceased; thus it could be concluded that the washout period of 4 weeks was not long enough to eliminate carryover benefits from the fish oil.

In a 1987 investigation at the Harvard Medical School, which primarily examined potential mechanisms of the action of fish oil dietary supplements in patients with RA, 12 patients with active disease consumed $3.6 \mathrm{~g}$ EPA and $2.4 \mathrm{~g}$ DHA daily over a period of 6 weeks [36]. All but 2 patients were on NSAIDS prior to the trial, and this regime was maintained. There was a significant decrease in the joint pain index and patient assessment of pain at 6 weeks; however, there were no significant changes in other disease parameters (see Table 1). The authors observed a suppression of LTB4 generation of 33\% from baseline after 6 weeks. Platelet-activating factor (PAF) production was less after 6 weeks compared with baseline pre-diet values (see Table 2). Thus PAF could contribute to the local inflammatory response by facilitating the movement of proinflammatory cellular elements from the circulation to the synovial tissue. The AA content declined significantly, and the ratio of AA to EPA decreased from $81: 1$ to $27: 1$. The results suggest the need for a large, long-term, randomized, double-blind, placebocontrolled study to elucidate the mechanisms involved.

In a 1988 investigation at the Royal Adelaide Hospital, South Australia, 46 patients with active RA completed a 12-week, double-blind, placebo-controlled study involving fish oil versus olive oil dietary supplementation [37]. Subjects consumed $3.2 \mathrm{~g}$ EPA/day and $2.0 \mathrm{~g}$ DHA/day or $1.0 \mathrm{~g} /$ day olive oil and continued background medications of NSAIDS, DMARDS, and prednisone unchanged. Dietary advice was provided to achieve total fat intake of $60 \mathrm{~g} /$ day including the supplements in both experimental and control groups. There were no observed improvements after the fourth and eighth weeks of fish oil supplementation; however, by the twelfth week, significant improvements in grip strength and tender joint score occurred (see Table 1). LTB4 levels decreased by $30 \%$ (see Table 2), and this inhibition suggests that the fish oil supplementation may have an antiinflammatory effect against a background of cyclo-oxygenase inhibition.

It is noteworthy that when significant improvements are observed, they often do not occur until at least after 12 weeks of dietary supplementation. Interleukin1 (IL-1) has a significant potential impact on the RA disease process through a variety of mechanisms $[28,38]$. It is relevant that fish oil dietary supplementation inhibits the production of this cytokine and that the chronology of these inhibitory effects differ from those observed with leukotriene production. The clinical benefits observed in the studies reviewed above may be delayed relative to the leukotriene inhibition because of the later inhibition of the production of IL-2.

Investigations prior to the 1990 study of Kremer et al. [39] employed the same dose of fish oil dietary supplementation irrespective of body weight. It is unclear whether dose-dependent effects of fish oil occur; however, it would be a 
logical extension of these studies to compare different doses over extended periods of time.

In their 1990 study at Albany Medical School, Kremer et al. followed 49 patients with active RA who consumed either a high or low dose of fish or olive oil over a period of 24 weeks. The study design was placebo-controlled, randomized, prospective, parallel, and double-blind. The low-dose fish oil group ingested $27 \mathrm{mg} / \mathrm{kg} /$ day EPA and $18 \mathrm{mg} / \mathrm{kg} /$ day DHA in ethyl ester form and the high-dose one ingested twice that amount. The olive oil group consumed $6.8 \mathrm{~g}$ of oleic acid, $0.93 \mathrm{~g}$ of palmitic acid, $0.53 \mathrm{~g}$ of linoleic acid, and $0.13 \mathrm{~g}$ of stearic acid/day. All patients maintained their DMARD regime. Significant changes from baseline increased with increasing duration of fish oil ingestion beyond 12 weeks. Only five clinical outcomes revealed improvement during week 6 to 12 in the fish oil group, whereas 24 outcomes achieved significance at the time of the 18-, 24-, and 30-week evaluation (see Table 1). IL-1 production and release decreased by $40.6 \%$ from baseline in the low-dose fish oil group and by $54.7 \%$ in the high-dose group. IL1 also decreased by $38 \%$ in the olive oil group, but this was not statistically significant (see Table 2). Olive oil (n-9) has the potential to favorably affect the immune response in inflammatory diseases [39].

A 1990 study having a randomized, double-blind, placebo-controlled, crossover design, was conducted in The Netherlands with 16 RA patients over 12 weeks [40]. EPA (2.04 g) and DHA (1.32 g) were allocated to the experimental group and coconut oil (quantity not given) was given to the control group. None of the patients were receiving steroids or cytotoxic drugs. Dietary fat intake was kept constant and food diaries were reviewed fortnightly. There was no washout period in the trial. The study claimed to show that dietary fish oil supplementation is effective in suppressing clinical symptoms of RA (see Table 1), even though the changes in laboratory indices were not statistically significant.

The authors of the above Netherland study claimed that as no correlations were found between changes in the leukotriene production and the significantly altered disease variables (which were only statistically significant for two clinical parameters), there must have been another factor, one other than the lipoxygenase pathway, that was responsible for the improvement. The significance of this study is not clear, and the crossover study design is considered inappropriate for fish oil studies.

Fish oil has been shown to reduce the release of PAF from immune cells after stimulation with appropriate agents. It has been proposed that PAF may be involved in the inflammatory response [27]. Thus n-3 fatty acid dietary supplementation may prove to be beneficial in RA patients; however PAF production and the effect of n-3 dietary supplementation in RA patients has not been fully elucidated [28]. The evidence of down regulation of PAF synthesis and the clinical improvement observed in small clinical trials of short duration, suggests that larger, well designed trials are necessary to determine the role of n-3 fatty acids in the inflammatory process and RA [36].

Vol. 20, No. 2, 1996 
The results of a 1992 study conducted at the Nizam Institute of Medical Science, Hyderabad, India, on pneumonia, septicaemia and collagen vascular diseases (including RA) suggested that fatty acids, free radicals, and cytokines interact with each other and that these molecules may play a significant role in the pathophysiology of infection, progression of disease, and the long-term prognosis of conditions such as RA [30]. This study investigated the effects of essential fatty acids on activated neutrophils, lymphocytes, and macrophages, as well as tumor necrosis factor (TNF), IL-1, IL-2, free radicals, and interferons and their effect on phospholipase A2, which enzyme activates AA, and thus contributes to acute and chronic inflammation.

A Swedish study conducted in 1992 involving 46 patients over 6 months utilized measures at commencement, and at 3 and 6 months in a randomized, controlled, double-blind study [41]. EPA (1.8 g) and DHA (1.2 g) were allocated to the experimental group, whereas the control group consumed 10 capsules/day of a mixture of olive, maize and peppermint oils. Patients were asked to maintain their usual diet and medication during the experimental period, with the option of decreasing their NSAID medication if desired. Experimental patients reported a significantly decreased consumption of NSAIDS at 3 and 6 months. No change was found in patient assessment of pain, duration of morning stiffness, and functional capacity (see Table 1) or in biochemical markers of inflammation (see Table 2).

A 1992 Danish study was conducted with 57 patients over 12 weeks in a multicenter double-blind, randomized, placebo-controlled trial [42]. EPA (2.0 g) and DHA (1.2 g) were allocated to the experimental group, and the control group consumed a mixture of fatty acids comparable to that found in the normal Danish diet. No dietary instruction was given, but patients were asked to continue their ordinary diet and medication throughout the study period. Significant improvement in morning stiffness and joint tenderness was observed (see Table 1).

A Scottish study in 1993 involving 64 patients in a 12-month, double-blind, placebo-controlled trial was divided into two sections [43]. At baseline, patients received either 10 maxEPA $(1 \mathrm{~g}$ ) capsules or 10 airfilled placebo capsules for 12 months and were assessed at 3-month intervals. At the end of the 12 months, patients were allocated to a single blind placebo phase for 3 months. There was a significant reduction in NSAIDS usage with patients consuming the maxEPA capsule. The effect reached a maximum at 12 months and persisted to 15 months. These patients were able to reduce their NSAIDS requirement without deterioration in clinical and laboratory parameters of rheumatoid arthritis (see Table 1).

A Belgium study in 1994 involving 90 patients in a 12-month, double-blind, randomized, placebo-controlled study comparing daily supplementations of $2.6 \mathrm{~g}$ of $\mathrm{n}-3$ fish oil or $1.3 \mathrm{~g} \mathrm{n}-3+3 \mathrm{~g}$ of olive oil or $6 \mathrm{~g}$ olive oil [6]. A normal stable diet of approximately $30 \%$ fat, $12-15 \%$ protein, $50-58 \%$ carbohydrate, animal fat $<100 \mathrm{~g} /$ day and NSAIDS and/or DMARDS was maintained throughout the study. Dietary supplementation with n-3 fatty acids results in some significant 
beneficial clinical effects and may lessen the need for NSAIDS/DMARDS (see Table 1).

Most medical practitioners are unwilling to recommend fish oil supplements to their patients with RA because of the confusion surrounding the amount to prescribe, the overall effectiveness, and the additional expense of an unproven remedy. There is thus a need to better define the overall therapeutic effect of fish oil and to place these dietary supplements in the appropriate niche in relation to NSAID and DMARD. Studies are required to determine whether patients consuming fish oils for a sufficiently long period ( $>18$ weeks) could discontinue NSAIDS without deterioration of their clinical status. Investigations should also monitor background diet to avoid n-6 competition at the cellular level. It is necessary to determine the critical variables that modulate the effects of dietary supplementation of n-3 fatty acids on the mechanism of inflammation $[3,6,7,44]$.

The role of the clinician/medical practitioner should be to discourage the adoption of unproven dietary regimes and to correct the dietary imbalance of $n$ 3 and $n-6$ fatty acids. The dietary imbalance is primarily due to a high intake of vegetable oils and a limited intake of fish and other seafoods. The correction of this dietary imbalance between n-3 and n- 6 fatty acids may be achieved by the use of encapsulated fish oil, dietary fortification with n-3 PUFA or a linolenic-rich diet in combination with a background diet low in linoleic acid [45, 46]. As the degree of unsaturation of cell membranes increases as a result of dietary modification, the risk of lipid peroxidation and generation of free radicals increases, thus it is necessary to include sources of $\alpha$-tocopherol to prevent this occurrence [47].

\section{EFFECTIVE DOSE OF N-3 FATTY ACIDS}

The complexity of inflammation and the incompleteness of our understanding of the mechanics of inflammation dictate that the efficiency of an intervention must be well tested before generalizations may be drawn. Several well-controlled studies of n-3 fatty acid supplements in patients with RA demonstrate anti-inflammatory effects in clinical parameters; however, as the levels of these supplements increase (up to $6 \mathrm{~g} /$ day), the clinical effects are modest and it is questionable that higher daily doses of n-3 fatty acid supplements would yield more significant therapeutic effects. Early studies used fixed daily doses of n-3 fatty acid supplements without regard to the individual's body weight [33-37]. The possibility that there could be dose-dependent clinical and biochemical effects of $n-3$ supplementation should be considered. Many studies have been conducted over short time spans of 6-14 weeks [33-37]; however it appears that some of the biochemical parameters increase from baseline measures after 14 weeks [39].

Because of the increasing amounts of n-6 fatty acids in the western diet, the eicosanoid metabolic products from AA are formed in larger quantities than those formed from n-3 fatty acids. The eicosanoids from AA are biologically active in 
very small amounts and if they are formed in large amounts, contribute to a physiologic state that is prothrombotic, proaggregatory, and proinflammatory. None of the studies to date have specifically controlled for $n-3: n-6$ ratios; thus, if background diets are high in polyunsaturated fatty acids (high PUFA), the products of AA will be formed rather than the products of EPA-n-3 fatty acids (low PUFA) [9, 38, 48]. It is possible that dietary control of the $n-3: n-6$ ratio could be more effective than the large doses of $n-3$ fatty acids of $6 \mathrm{~g} / \mathrm{day}$.

\section{CONCLUSIONS}

1. Crossover experimental design is not appropriate in fish oil dietary supplementation because of the long carry over benefits of $n-3$ fatty acids. Wash out periods could be as long as 18 weeks, which can negate the advantages provided by crossover trials through seasonal variations in diet [35, 49].

2. The length of investigation should continue beyond 12 weeks. It has been noted that the time taken to alter cellular lipid levels and subsequent immune cell production takes much longer. Twenty-four weeks of investigation has been proposed $[39,49]$.

3. There is a limit to the amount of fish oil supplements that can be accepted in the western diet. Research methodology reviewed utilized increased amounts of fish oil for supplementation, but without overall increases in statistically significant improvement in clinical and biochemical parameters. It is now clear that the clinical benefits are dose related, and it is thus recommended that doses be calculated as $\mathrm{mg} / \mathrm{kg}$ IBW/day [38, 39, 44].

4. It has been established experimentally that fish oil dietary supplementation decreases LTB4 and IL-1 production as well as alters TNF and T and B cell reactivity. An aspect that has not been elucidated is that of lipoxygenase pathway inhibition as the reason for improvement in clinical parameters [28].

5. At present it has not been established whether EPA or DHA are responsible for mediating the anti-inflammatory response of n-3 fatty acids. Further studies are required to clarify this aspect of the mechanism of inflammation [44].

6. Studies have revealed varying responses to n-3 fatty acid supplementation, which may be attributed to the EPA/DHA ratio [44], a dose-dependent effect [38], n-6 content of background diets too high in comparison to the $n-3$ content of the diet [48], or to the possibility that the placebo fatty acid may have some biologic or clinical effects [6].

7. Inflammatory stimuli result in cytokine production and free radical release that may enhance the production of TNF and cytokines other than those produced through the cyclo-oxygenase and 5-lipoxygenase enzyme systems as well as the PAF system. The mechanisms involved require further evaluation $[49,50]$.

8. Dietary supplementation with olive oil is also associated with certain changes in immune function that require further investigation. Beneficial effects have been ascribed to oleic acid, a monounsaturated fatty acid (MUFA) (18:1) 
found in olive oil. The immune effects of oleic acid ingestion have been demonstrated; however, further studies on the effects of MUFA on clinical and immune variables in patients with RA are warranted $[6,39,51]$.

\section{REFERENCES}

1. Roitt, I. (1991): Essential Immunology, Blackwell Scientific Publication, Oxford, pp. 305342.

2. Hochberg, M.C., Chang, R.W., Dwosh, I., Lindsey, S., Pincus, T., and Wolfe, F. (1992): The American College of Rheumatology 1991, revised classification of global functional status in rheumatoid arthritis. Arthritis Rheum., 35, 498-502.

3. Trentham, D.E. (1993): New focus on treatment for rheumatoid arthritis. Curr. Opin. Rheumatol, 5, 178-183.

4. Felson, D.T., Anderson, J.J., Boers, M., Bombardier, C., Chernof, M., Fried, B., First, D., Goldsmith, C.H., Kiezak, S., and Lightfood, R. (1993): The American College of Rheumatology preliminary core set of disease activity measures for rheumatoid arthritis clinical trials. Arthritis Rheum., 36, 729-740.

5. Day, R.O. (1988): Mode of action of nonsteroidal anti-inflammatory drugs. Med. J. Aust., 148, 195-199.

6. Guesens, P., Wouters, C., Nijs, J., Jiang, Y., and Dequeker, J. (1994): Long term effect of omega-3 fatty acid supplementation in active rheumatoid arthritis. Arthritis Rheum., 37, 829-834.

7. Kjeldsen-Kragh, J., Lund, J.A., Riise, T., Finnanger, B., Haaland, K., Finstad, R., Mikkelsen, K., and Forre, O. (1992): Dietary omega-3 fatty acid supplementation and naproxen treatment in patients with rheumatoid arthritis. J. Rheumatol., 19, 1531-1536.

8. Edmonds, J.P., Scott, D.L., and Furst, D.E. (1993): Anti-rheumatic drugs: A proposed new classification. Arthritis Rheum., 36, 336-339.

9. Simopoulos, A.P. (1991): Omega-3 fatty acids in health and disease and in growth and development. Am. J. Clin. Nutr., 54, 438-463.

10. Van Reil, P.L., and Van de Putte, L.B. (1994): Clinical assessment and clinical trials in rheumatoid arthritis. Curr. Opinion Rheumatol., 6, 132-139.

11. Larkin, J.G. (1994): Alternative medicine and rheumatoid arthritis. Rheumatol. Rev., 3, 6171.

12. Haugen, M., Kjeldsen-kragh, J., Nordvag, B.Y., and Forre, O. (1991): Diet and disease symptoms in rheumatic diseases-results of questionnaire based survey. Clin. Rheumatol, 10, 401-407.

13. Panash, R.S. (1993): Reflections on unproven remedies. Rheum. Dis. Clin. North Am., 19, 201-206.

14. Panash, R.S., Cai, P., Chuzchin, Y., Cintron, M., Kramer, N., Paolino, J., Rosenstein, E.D., Janelli, M., and Smith, L.J. (1994): Nutritional therapy for active arthritis in pregnant or breast feeding women. J. Rheumatol., 21, 967-978.

15. Merry, P., Kidd, B., and Blake, D. (1989): Modification of rheumatoid symptoms by diet and drugs. Proc. Nutr. Soc., 48, 363-369.

16. Lee, T.H., and Arm, J.P. (1988): Benefits from oily fish. Br. Med. J., 297, 1421-1422.

17. Houston, L. (1994): Dietary changes in arthritis. Practitioner, 238, 443-448.

18. Darlington, L.G., and Ramsey, N.W. (1993): Review of dietary therapy for rheumatoid arthritis. Br. J. Rheumatol., 32, 507-514.

19. Yetiv, J.Z. (1988): Clinical applications of fish oils. J. Am. Med. Assoc., 260, 665-670.

20. Kromhout, D., Bosschieter, E.B., and Coulander, C. (1985): Inverse relationship between fish consumption and 20 year mortality from coronary heart disease. N. Engl. J. Med., 312, 1205-1209.

Vol. 20, No. 2, 1996 
21. Bates, E.J., Ferrante, A., Harvey, D.P., and Poulos, A. (1993): Polyunsaturated fatty acids increase neutrophil adherence and integrin receptor expression. J. Leukocyte Biol., 53, 420426.

22. Danno, K., Ikai, K., and Imamura, S. (1993): Anti-inflammatory effects of eicosapentaenoic acid on experimental skin inflammation models. Arch. Dermatol. Res., 285, 432-435.

23. Ferrante, A., Goh, D., Harvey, D.P., Robinson, B.S., Hii, C.S., Bates, E.J., Hardy, S.J., Johnson, D.W., and Poulos, A. (1994): Neutrophil migration inhibitory properties of polyunsaturated fatty acids. The role of fatty acid structure, metabolism and possible second messenger systems. J. Clin. Invest., 93, 1063-1070.

24. Holub, B.J. (1993): Omega-3 fatty acids: Candidate nutrients ?, in Nutritional Essentiality: A Changing Paradigm, Report on the 12th Conference on Medical Research, Ross Products Division, Abbott Laboratories, Colombus, Ohio, pp. 29-33.

25. Nakamura, N., Hamazaki, T., Kobayashi, M., and Yazawa, K. (1994): The effect of oral administration of eicosapentaenoic and docosahexaenoic acids on acute inflammation and fatty acid composition in rats. J. Nutr. Sci. Vitaminol. (Tokyo), 40, 161-170.

26. Robinson, D.R. (1991): Alleviation of autoimmune disease by dietary lipids containing omega-3 fatty acids. Rheum. Dis. Clin. North Am., 17, 213-222.

27. Sperling, R. (1991): Dietary omega-3 fatty acids: Effects of lipid mediators of inflammation and rheumatoid arthritis. Rheum. Dis. Clin. North Am., 17, 373-389.

28. Sperling, R. (1991): Effects of dietary fish oil on leucocyte, leukotriene and PAF generation and on neutrophil chemotaxis, in Health Effects of Omega-3 Polyunsaturated Fatty Acids in Seafoods: World Review of Nutrition and Dietetics, Vol. 66, ed. by Simopoulos, A., Kifer, R., Martin, R., and Barlow, S., Karger, pp. 391-400.

29. Das, U., Ramesh, G., Sravan Kumar, G., Madhavi, N., Vijay Kumar, K., Sangeetha, P., Koratkar, R., and Padma, M. (1992): Free radicals, lipid peroxidation and essential fatty acids in patients with pneumonia, septicemia and collagen vascular disease. J. Nutr. Med., 3, $117-127$.

30. Das, U. (1994): Beneficial effect of eicosapentaenoic and docosahexaenoic acids in the management of systemic lupus erythematosus and its relationship to the cytokine network. Prostagland., Leuko. Essent. Fatty Acids, 51, 207-213.

31. Endres, S., Ghorbani, R., and Kelly, V. (1989): The effect of dietary supplements with n-3 polyunsaturated fatty acids on the synthesis of interleukin-1 and tumour necrosis factor by mononuclear cells. N. Engl. J. Med., 320, 265-271.

32. Turner-Stokes, L. (1993): Haematology, in Oxford Textbook of Rheumatology, ed. by Maddison, P.J., Oxford University Press, New York, pp. 367-375.

33. Panash, R., Carter, R., Katz, P., Lowsari, S., and Finnie, S. (1983): Diet therapy for rheumatoid arthritis. Arthritis Rheum., 26, 462-471.

34. Kremer, J.M., Michalek, A.V., Lininger, L., Huych, C., Bigaouette, J., Timchalk, M.A., Rynes, R.I., Zieminski, J., and Bartholomew, M. (1985): Effects of manipulating dietary fatty acids on clinical manifestations of rheumatoid arthritis. Lancet, I, 184-187.

35. Kremer, J.M., Jubiz, W., Michalek, A., Rynes, R., Bartholomew, L.E., Bigaouette, J., Timchalk, M., Beeler, D., and Lininger, L. (1987): Fish-oil fatty acid supplementation in active arthritis. Ann. Intern. Med., 106, 497-503.

36. Sperling, R., Weinblatt, M., Robin, J., Ravalese, J.I., Hoover, R., House, F., Coblyn, J.S., Fraser, P., Spur, B.W., Robinson, D.R., Lewis, R.A., and Austen, K.F. (1987): Effects of dietary supplementation with marine oil on leucocyte lipid mediator generation and function in rheumatoid arthritis. Arthritis Rheum., 30, 988-997.

37. Cleland, L.G., French, J., Betts, H.W., Murphy, G., and Elliott, M. (1988): Clinical and biochemical effects of dietary fish oil supplements in rheumatoid arthritis. J. Rheumatol., 15, $1471-1475$.

38. Robinson, D.R., and Kremer, J.M. (1991): Rheumatoid arthritis and inflammatory mediators, in Health Effects of Omega-3 Polyunsaturated Fatty Acids in Seafoods: World Review of Nutrition and Dietetics, Vol. 66, ed. by Simopoulos, A., Kifer, R., Martin, R., and 
Barlow, S., Karger, pp. 44-47.

39. Kremer, J., Lawrence, D., Jubliz, W., Di Giacomo, R., Rynes, R., Bartholomew, L.E., and Sherman, M. (1990): Dietary fish oil and olive oil supplementation in patients with rheumatoid arthritis: Clinical and immunological effects. Arthritis Rheum., 33, 810-820.

40. Van der Tempel, H., Tulleken, J., Limburg, P., Muskiet, F.A.J., and Van Rijswijk, M.H. (1990): Effecs of fish oil supplementation on rheumatoid arthritis. Ann. Rheum. Dis., 49, 76 80 .

41. Skoldstam, L., Borjesson, O., Kjallman, A., Seiving, A., and Akesson, B. (1992): Effect of six months of fish oil supplementation in stable rheumatoid arthritis. Scand. J. Rheumatol., 21, 178-185.

42. Nielsen, G.L., Faarvang, K.L., Thomsen, B.S., Teglbjaerg, K.L., Jensen, J.T., Hansen, T.M., Lervang, H.H., Schmidt, E.B., Dyerberg, J., and Ernest, E. (1992): The effects of dietary supplementation with n-3 polyunsaturated fatty acids in patients with rheumatoid arthritis: A randomized double blind trial. Eur. J. Clin. Invest., 22, 687-691.

43. Lau, C.S., Morley, K.D., and Belch, J.J. (1993): Effects of fish oil supplementation on nonsteroidal anti-inflammatory drug requirement in patients with mild rheumatoid arthritis-a double blind placebo controlled study. Br. J. Rheumatol., 32, 982-989.

44. Garg, M.L., and Li, T. (1994): The importance of dietary eicosapentaenoic acid to docosahexaenoic acid ratio in modulation, of serum lipid and arachidonic acid levels. Nutr. Res., 14, $1575-1582$.

45. Sinclair, A., O'Dea, K., and Johnson, L. (1994): Estimation of n-3 status of a group of urban Australians by analysis of plasma phospholipid fatty acids. Aust. J. Nutr. Diet., 51, 53-56.

46. Sinclair, A., O’Dea, K., Dunstan, G., Ireland, P.D., and Naill, M. (1987): Effects on plasma lipids and fatty acid composition of very low fat diets enriched with fish or kangaroo meat. Lipids, 22, 523-529.

47. Tulleken, J.E., Limburg, P.C., Muskiet, F.A.J., and Van Rijswijk, M.H. (1990): Vitamin status during dietary fish oil supplementation in rheumatoid arthritis. Arthritis Rheum., 33, 1416-1419.

48. Mantziores, E., James, M.J., Gibson, R.A., and Cleland, L.G. (1994): Dietary substitution with alpha linolenic acid rich vegetable oil increases eicosapentaenoic acid concentrations in tissues. Am. J. Clin. Nutr., 59, 1304-1309.

49. Kremer, J.M. (1991): Clinical studies of omega-3 fatty acid supplementation in patients who have rheumatoid arthritis. Rheum. Dis. Clin. North Am., 17, 391-402.

50. Grimble, R.F. (1992): Dietary manipulation of the inflammatory response. Proc. Nutr. Soc., 51, 285-294.

51. Cleland, L.G., James, J., Neumann, M.A., D’Angelo, M., and Gibson, R.A. (1992): Linoleate inhibits EPA incorporation from dietary fish oil supplements in human subjects. J. Clin. Nutr., 55, 395-399. 